\title{
Higher Education Finance Between Ghana and the United States
}

\author{
Alfred Acquah \\ University of Nevada, Las Vegas
}

\begin{abstract}
Over the years, there has been a tremendous increase in enrollment in higher education as well as the cost of attendance. This article comparatively analyzes the higher education finance between the United States of America (U.S.A.) and Ghana, taking into consideration the goals of higher education, enrollment and expenditure, and the various sources of finance available to students in both countries. The source of education finance between both countries is examined through the lens of neoliberalism, which prioritizes capitalism, free trade, and market in public institutions, specifically higher education. While there are disparities in the financing of higher education in both countries, there is a similarity in the limited access to higher education and funding by students from low socioeconomic backgrounds.
\end{abstract}

\section{Introduction}

The escalating cost of higher education in recent years has been felt by many countries around the world and has attracted a lot of attention, with some studies attributing the high cost to inadequate public funding, growing pressure on public funding, and in some cases, economic recession (Acheampong, 2010; Klein, 2015; Liu, 2018; Tulip, 2007). According to the World Bank, higher education refers to all post-secondary education, including private and public universities, colleges, technical and vocational institutions. Also, higher education is seen as an instrument and key in providing solutions to intricate problems. It is also perceived as an economic engine that frees people from poverty by providing them with high-paying jobs (Morton, 2018). Higher education, which used to be a service for the elite, is now a service for the mass due to higher demand by all classes of people. In recent times, higher education has seen a massive expansion. For example, the worldwide Gross Tertiary Enrollment Ratio (GTER) increased to $32 \%$ in 2012 compared to 10\% in 1972 (Marginson, 2016). There are about 200 million students enrolled in higher education in the world compared to 89 million in 1998 (The World Bank, 2017). As enrollment increases in higher education, the cost of attendance also increases. The increase in enrollment and high cost of higher education is seen as a result of the increased emphases on knowledge-based economy and neoliberal practices, the former measuring how knowledge or information contribute to the economy and the latter prioritizing competition, free market, and government budget cut (St. George, 2006; Gyamera \& Burke, 2018;). Knowledge-based economy has been described as one of the "three powerful economic narratives" in the past 30 to 40 years and has influenced educational reforms in public discourse. (Sum, \& Bob, 2013, p. 24). It has become more influential lately because it is championed by three world superstructures: The Organization for Economic Development and Cooperation (OECD), the World Bank, and the European 
Union (Sum, \& Bob, 2013). Through knowledge-based economy, education is now considered an economic industry that is evaluated based on its contributions to the economy. Thus, educational services are increasingly being privatized, open to global competition, and managed by non-academic personnel. Although the emphasis on knowledge-based economy has contributed to increased enrollment in higher education, it has also positioned education in a neoliberal perspective accounting for the high cost of higher education. Besides, the limited access to higher education, funding, and the complications that accompany the securing of student loans deny students from low socioeconomic backgrounds from enrolling in higher education (Klein, 2015; Okrah \& Adabor, 2010).

The purpose of this paper is to examine the sources of higher education finance available in Ghana and the U.S. and understanding how practices of neoliberalism have impacted them. The paper compares the higher education finance of Ghana and the U.S. due to their historical connection in education. It analyzes the goals of education, higher education enrollment, and expenditure in both countries. This paper aims to contribute to the literature on comparative higher education between Ghana (a "developing" country) and the U.S. (a developed country) who is more advanced in higher education and serves as a measure of a standard to other countries.

\section{Background information}

According to the United Nations, the U.S. is the third most populous nation in the world with a population of $329,064,917$ in 2019, while Ghana has a population of 28,833,629 and serves as the forty-eighth most populous nation in the world. In 2019, there were about 19.73 million and 496,148 students enrolled in U.S. and Ghana higher education, respectively (Duffin, 2020; Sasu, 2020). According to a statistical report released by the National Accreditation Board, Ghana, there are about 230 institutions of higher education in Ghana. In comparison, the USA has about 4,360 (as of 2016/2017) degree-granting institutions of higher education (National Center for Education Statistics [NCES], 2017). Enrollment into higher education in both countries is optional and not compulsory as compared to basic education.

Over the years, the cost of higher education in Ghana and the U.S., and other countries have risen due to a reduction in federal government funding (Acheampong, 2010; Tulip, 2007). This reduction in funds, as a result, puts more higher education cost burden on students and parents, contributing to an increase in student loans. On average, $68 \%$ of students in the U.S. higher education graduate with about \$30,000 in loans (Morton, 2018). According to a report by the National Center for Education Statistics (NCES, 2019), the annual average cost of higher education in the U.S. was $\$ 24,300$ for public four-year institutions and $\$ 50,300$ for private four-year institutions for the 2017/ 2018 academic year. This applied to students who lived on campus. Students who lived with the family spent $\$ 14,400$ and $\$ 39,900$ in public and private schools, respectively. Those who lived offcampus without family spent $\$ 24,200$ and $\$ 50,200$ in public and private schools, respectively (NCES, 2019). 
According to Enterversity (2021), a free university search engine for students in Africa, the average cost of higher education in Ghana for public institutions is between GH $\$ 1400$ (\$243.45) to GH\$2100 (365.17). The cost of higher education in private institutions is between $\mathrm{GH} \$ 5,000$ (\$869.46) to $\mathrm{GH} \$ 9,000(\$ 1,565.03)$ (Enterversity, 2021). This amount is a little more expensive for the average Ghanaian. In order for students to become aware of these increments and the cost of higher education, it is vital that students are as well exposed to the different sources of funding available to them. Oseni et al. (2018) propose that one of the important aspects of education finance is the source of funding available to students. They argue that sources of funding should be explicitly stated in order to be able to synthesize with other sources of funding (Oseni et al., 2018).

Although Ghana was colonized by the British, the U.S. has a greater educational transfer role, a core ground for comparative education research, on Ghana. For example, an American concept of education, the Hampton-Tuskegee model of industrial education, was first borrowed by the Achimota College (now Achimota School) situated in Accra, Ghana, before it spread to other British colonies in Africa. (Steiner-Khamsi \& Quist, 2000). During the 1920s, Phelps-Stokes Fund, a New York-based philanthropic agency, saw the spreading of the American education model (industrial education), which was mainly designed for African Americans in the Southern U.S., to the African continent. Ghana, then Gold Coast, became the first country to adjust to the education model of the U.S. (Steiner-Khamsi \& Quist, 2000).

This educational transfer was spearheaded by America's Booker T. Washington and Ghana's James E. K. Aggrey, a co-founder of Achimota College (Newkirk, 2012). The historical connection between Ghana and the U.S. may have contributed to the increasing similarity in both countries' education systems. Also, the U.S. has, over the years, become the number one study abroad destination for most international students from Ghana. For example, the U.S. recorded 4,221 international students in the 2019/2020 academic year, indicating a 15.3 percent increase from the previous year (Institute of International Education, 2021). The adaptation of the American education model by Ghana and the flow of international students shows the historical connection between the two countries. Yet, there is a dearth of literature comparing certain key aspect such as higher education finance between these two countries. This paper aims to address this gap in the literature. Hence the comparison.

\section{Literature Review}

This section reviews the literature on higher education funding, including performancebased funding, which has gained prominence in recent years. I summarize the findings of prior studies on the consequences of low public funding on students and families.

Public universities all over the world are affected by budget cuts from the increasingly inadequate government funding resulting in increased tuition and fees in countries where they exist and more so imposing them where until now did not exist (St. George 2006; Klein, 2015; Newman \& Duwiejua, 2015; Salmi, 2003; Schugurensky, 2013). For example, tuition and fees are now enforced in places like Latin America and Europe, previously tuition-free. As a result of the steep rise in the cost of higher education, loan plans have 
been introduced by several higher education institutions and countries over the years (Salmi, 2003). Examples of such loan schemes include the Stafford Loan and the Student Loan Trust Fund (SLTF) of the U.S. and Ghana, respectively (Darvas et al., 2017; Federal Students Aid, n.d.; Library of Congress, 2005). These loans are repaid by students after graduation (Salmi, 2003). As government funding for higher education continues to shrink, many OECD countries, including Ghana and the U.S., have implemented the performance-based type of funding.

Funding for higher education is being increasingly based on institutions' performance, known as performance-based funding, which shifts higher education funding, normally based on factors such as enrollment and expenditure, to one based on results and outcomes. That is, state or public funds are linked directly to Institution outcomes (Doh \& Doh, 2013; Dougherty et al., 2014; Dougherty \& Natow, 2015). In a new proposal for higher education funding in Ghana, performance-based funding was enacted as one strategy to distribute public funds to higher education institutions (Newman \& Duwiejua, 2015). This means that one of the criteria for allocating public funds to any institution would be based on the output or contribution to the economy. The proposal referenced the performance-based funding used by the Tennessee Higher Education Council as a model (Newman \& Duwiejua, 2015). The performance-based model, which began in the Tennessee U.S. in 1979, was in the form of bonus money aside from the base funding from the state. In the U.S., about 38 States had enacted performance-based funding in 2014 (Dougherty et al., 2014; Dougherty \& Natow, 2015; Dougherty \& Natow, 2019).

In a study to explore performance-based funding's impact on state appropriation, Hagood (2019) found that performance-based funding was favorable to some schools over others. The results from the study indicated that this type of funding mostly benefits higher education institutions that are research-oriented, highly resourced, and highly selective but posed burdens to the low-resourced institution of higher education. The study found that performance-based funding may promote a-winner-loser situation among schools by rewarding highly resourced institutions and punishing those with fewer resources. The author advised that a more equitable distribution of public funds that takes an institution's resources into consideration be implemented in higher education.

Also, in a study on performance funding in the U.S. states of Ohio and Pennsylvania, Zumeta and $\mathrm{Li}$ (2016) found that there were differences in institutional strength to respond to the demands of performance-based funding adequately. Using purposeful sampling, the authors recruited and interviewed 42 administrators, faculty, and advisors. The authors found that performance-based funding has the likelihood of worsening the gap between the highly-resourced institutions and the least-resourced institutions (Zumeta \& Li, 2016). The highly resourced institutions have all well-qualified faculty and staff and access to varied resources for meeting the requirements of performance-based funding. In contrast, institutions with fewer resources are cannot meet the requirement, creating winners and losers (Zumeta \& Li, 2016). These studies suggest that performancebased funding is more favorable to higher education institutions that are well resourced, placing them in an advantageous position over those with fewer resources. This brings 
about competition among institutions and creates a winner-loser dichotomy among schools.

Other studies in higher education funding have shown the challenges students and families face relative to the inadequate public funding (Asamoah, 2017; Goode, 2017). The cost of higher education and the reduction in government subsidies has become a barrier to accessing higher education. In a study to explore how the components of the U.S. 2year community college model might be adapted by Ghana to address the limited access, limited facilities, inadequate programs, and high cost in higher education, Goode (2017) found that most participants attributed the barrier to higher education in Ghana to the high tuition cost especially to low-income students. Participants from the study noted that although loans and grants were available to students, the system of distribution was unfair to students from working-class and middle-class families. Similarly, Asamoah (2017) found that the high cost of tuition fees was a major challenge to students in Ghana. The findings indicated that, low-income students who make up the majority of the undergraduate student population could not afford the cost of their education. Participants also lamented the high cost in private institutions because they were excluded from receiving a share of the public fund.

The findings from this body of research suggest that the rising cost of higher education is a key concern to students and families, especially those from low socioeconomic backgrounds. Also, students from low-income backgrounds may not have the means to access available funding due to inequitable funding distribution mechanics.

\section{Theoretical Lens}

This paper utilizes the framework of neoliberalism in understanding higher education financing in Ghana and the United States. Neoliberalism refers to political and economic practices that minimize public interventions but prioritize free-market, free trade, and competition as the means through which institutions and people can achieve favorable and greater outcomes (Harvey, 2007; Stromquist \& Sanyal, 2013). Neoliberalism emphasizes capitalism, privatization, and free market in public spaces (e.g., public institutions of higher education), increasing the influence of ones' socioeconomic background in their educational trajectory (Weis et al., 2020). This system results in meritocracy, competition, and decentralization in higher education. It even contributes to the reduction in government funds for schools forcing higher education institutions to modify their curriculum to meet the demands of the international economy (Gyamera \& Burke, 2018). Besides, guidelines of participation are now created through international organizations like the World Bank and the International Monetary Fund (IMF), which are now inevitable in almost every nation-state and "instantiates neoliberalism as a global set of rules" (Harvey, 2007, p. 23). Usually, countries affiliated with these superstructures are directed or mandated to adjust to the policies, such as reducing government funds to higher education institutions. This puts pressure on schools to increase tuition and fees, adjust their curriculum to reflect the international standards, and start to operate as a forprofit organization turning the university into a private good where students have to pay huge sums of money to purchase as any other good in the market. The pressure is mostly felt more by developing countries like Ghana, which have limited resources and receive 
support from donors (Altbach, 2015; Harvey, 2007). In order to generate more income, institutions concentrate more on attracting international students into their programs, which raises their status on the international rankings of schools Lee, 2010). For example, international students contributed 41 million to the U.S. economy in 2018/ 2019 (National Association for Foreign Student Affairs [NAFSA], 2020). Previously, Ghana reserved five percent of admission slots to international students but is now proposed to increase to 15 percent, paying the full cost of their tuition (Badoo, 2013; Newman \& Duwiejua, 2015). Also, the U.S. receives the highest number of international students, with about 1,075,496 international students. (Becker \& Kolster, 2012; Institute of International Education, 2021). Neoliberalism also has the aim of just providing the skills that are needed by students in securing jobs in the global economy. In the introduction of their article "Neoliberalism and curriculum in higher education: a post-colonial analysis," Gyamera and Burke (2018) talk about the adverse effect of neoliberalism to include the strong emphasis on the private sector as the foundation for a countries development. As such, public institutions are pushed to generate income independently, which means cutting down the flow of government funding to schools (Gyamera \& Burke, 2018). They also emphasized how neoliberalism favors some groups (elite) over others (low-income families) relative to access to higher education (Gyamera \& Burke, 2018).

\section{Data and Methods}

The research was conducted using previous studies and documents. I searched for peerreviewed articles on online libraries and journals as well as search engines like Google Scholar. I also obtained information on higher education finance from government institution websites for data on goals of higher education, college enrollment, sources of funding, and expenditure. In addition, I obtained information on higher education finance from books on comparative and international education. Lastly, I retrieved information that is hard to find in the literature from funding from higher education institution websites. Key-search terms used in this review included higher education finance in Ghana, higher education finance in the U.S., sources of funding for higher education in Ghana, sources of financial aid in the U.S., neoliberalism, knowledge-based economy, globalization of higher education, and Historical connection between Ghana and the U.S. These search terms helped in finding relevant information which informed this paper.

\section{Goals of Higher Education in Ghana and the U.S.}

In Ghana, the National Accreditation Board (NAB), which is under the Ministry of Education, is one of the agencies responsible for the regulation, supervision, and accreditation of tertiary education institutions. There is also the National Council for Tertiary Education (NCTE) and the National Board for Professional and Technician Examinations (NABPTEX). Recently, the NAB and the NCTE have been merged to form the Ghana Tertiary Education Commission (GTEC), which is mandated to regulate higher education. Although the GTEC had no specific mission or goal stated on its website at the time of this article, there were pieces of information in its strategic plan that focused on the creating a vigorous, world-class higher education capable of competing globally. Besides, there was an emphasis on the need to standardize government programs in all disciplines and utilize technology in its operations (GTEC, 2021). Also, the Ministry of 
Education's vision is to provide education relevant to students at all levels (Ministry of Education, Ghana, n.d.).

On the GES website, there is a mission statement that pertains to only the technical and vocational education division. The mission is "to create an enabling environment for the youth to acquire quality demand-driven Technical and Vocational Education Training (TVET) employable skills and general education to enable them fulfill the country's TVET human resource requirements" (Ghana Education Service [GES], n.d., TVET section).

The goal of higher education in the U.S. is to "promote student achievement and preparation for global competitiveness by fostering educational excellence" (U.S. Department of Education, n.d.). Higher education goals in the United States vary due to their regulation by different private institutions. According to a report released by the U.S. Secretary of Education on March 21, 2019, the then president's executive order on higher education was "improving free inquiry, transparency, and accountability at colleges and universities" (U.S. Department of Education, 2019).

\section{Enrollment and Expenditure on Higher Education in Ghana and the U.S.}

In Ghana, investment in education as a percentage of GDP was 6-8\% between 2011 and 2015, representing 22-27\% of the Government's annual expenditure. In recent years, this has declined to $3.9 \%$ of the GDP in 2018 for education in general and 1.2\% in tertiary education in 2013, as last recorded by the World Bank (The World Bank, 2021). Also, 19.1\% of the government budget for education is apportioned to higher education (Newman \& Duwiejua, 2015). According to the United Nations Educational, Scientific and Cultural Organization (UNESCO) Institute of Statistics, Ghana had a total higher education enrollment of $15.7 \%$ in 2018 , compared to $11.8 \%$ in 2011, with the former representing about $2,879,063$ of the population aged 19 to 23 . The total enrollment of female students increased from $8.9 \%$ in 2011 to $13.6 \%$ in 2018 . On the other hand, enrollment for males increased from 14.5\% in 2011 to $17.7 \%$ in 2018 (UNESCO Institute of Statistics, 2021).

The total gross enrollment ratio in higher education in the U.S. was $88.3 \%$ in 2018, with $102.4 \%$ and $74.9 \%$ gross enrollment for females and males, respectively (UNESCO Institute of Statistics, 2021). In the U.S., the overall college enrollment rate for young adults (18 to 24 years old) increased from 35 percent in the year 2000 to 40 percent in 2017. Enrollment for females increased from $38 \%$ in 2000 to $44 \%$ in 2018, while men's enrollment rose from 33\% in 2000 to $38 \%$ in 2018 (NCES, 2020). Higher education outcomes vary from country to country depending on the investment made towards education. This can be measured in the number of students who complete higher education. Also, there is a higher percentage of women who have completed at least some college, according to the 2015 census. $60 \%$ of women had some college or more education as compared to $58 \%$ of men. Also, $32 \%$ of men and $33 \%$ of women had completed at least a bachelor's degree. There were $12 \%$ of both men and women who had completed an advanced degree (Ryan \& Bauman, 2016).

Furthermore, the U.S. federal government invests about $\$ 149$ billion in higher education, representing $3.6 \%$ of the federal government's expenditure. The amount increases to 
\$1.068 trillion with funding from non-federal funding agencies (Data Lab, n.d.). In 2016, the total government and private expenditure on all institutions was $6 \%$ as a percentage of the GDP and 2.5\% on higher education (NCES 2019). The U.S. government expenditure was $4.1 \%$ and $0.9 \%$ on all institutions and higher education, respectively (NCES, 2019). In other sectors like defense, health, and government pensions, the federal spend $5 \%, 8 \%$, and $7 \%$ of the GDP, respectively (U.S. Spending, 2020).

\section{Sources of Higher Education Funding in Ghana and the U.S.}

Higher education in Ghana used to be free, just like basic education. However, in the late 1980s and the early 1990s, the government could not increase and continue funds for supporting higher educational institutions due to low expenditure for higher education, and as a result, institutions of higher education had no choice but to charge high tuition fees (Dadzie, 2009). This was influenced by donor-backed policies and the World Bank's initiative of supplementing public income with income by shifting higher education costs from the government to students, parents, and people who purchase higher education services. They also emphasized high spending for primary and high school education to create high demand for higher education (Asamoah, 2017; Britwum \& Martins, 2008; World Bank, 1994). Since then, the government's aid for supporting higher education now comes in the form of government grants that are often shown in the national budget for developing higher education institutions (tertiary education). This fund is not the kind of aid that is disbursed to a student to complete or pay for tuition but is distributed to the various public institutions of higher education by the government through the Ghana Education Trust Fund (GETFund) as opposed to the U.S. Pell grant that contributes directly in paying students tuition fees. Other sources of funds for higher education institutions emanate from local authorities, internally generated funds by the institutions, tuition, and international organizations such as the World Bank (Pius, 2014).

The GETFund is an initiative enacted by the Ghanaian government to support all levels of education in the country. The fund was established by law in the year 2000 through the nation's parliament (Atuahene, 2006; Emeka, 2020). From the GETFund's online homepage, the trust fund is mandated to providing "funding to supplement government effort for the provision of educational infrastructure and facilities within the public sector from the pre-tertiary to the tertiary level" (GETFund, 2021., par. 1; Atuahene, 2015; Newman \& Duwiejua, 2015). This includes providing support to higher education institutions to acquire educational supplies and contribute to staff and research development. The trust provides aid in the form of scholarships and grants to needy but brilliant students. It also subsidizes academic facility user fees for higher education students. The GETFund, also a source of student loans, allocates money from its funds to support the student loan scheme's running to offer loans to students in accredited higher education institutions (Atuahene, 2015; GETFund, 2021). According to Atuahene (2015), the GETFund, despite all difficulties, is "making significant contributions towards higher education development in Ghana in infrastructure, student development, faculty research, and staff support" (p. 21).

Another source of government aid to students in higher educations in Ghana is the Students Loan Trust Fund (SLTF). The SLTF is a source of government funding in the 
form of loans for students in an accredited institution of higher education in Ghana. This trust fund was established in December 2005 under Act 820 of Ghana's parliament to support higher education institutions and students who are needy (Atuahene, 2008; Students Loan Trust Fund, 2020. The main sources of funds for the trust include but are not limited to; money from the GETFund, voluntary contributions and contributions from the private, and loans from the Social Security and National Insurance Trust (SSNIT). To qualify for SLTF, the applicant must first be a Ghanaian citizen and in need who is admitted to a nationally accredited institution of higher education for an academic program that is accredited by the National Accreditation Board. Besides, the student applicant must have a guarantor in order to be considered (Atuahene, 2008; Students Loan Trust Fund, 2020).

In addition to this, there are other forms of financial aids offered by the various higher education institutions in Ghana. An example is the Students Financial Aid offered by the University of Ghana as a measure to combat the increasing financial needs of their student applicants. This fund is awarded to brilliant but needy students. The fund pays for their academic fees and other expenses but contingent on the availability of funds. This could be in the form of a full or partial scholarship, on-campus work-study for students (University of Ghana, 2018).

\section{The United States}

In the U.S., federal student financial aid programs aim to assist students with or without low socioeconomic background. The federal student aid is categorized into three main types: (1) the federal aid, which consists of PELL grant, Stafford Loans, and Direct Plus Loan; (2) State Aid (merit and need-based scholarships); and (3) Institutional Aid. Firstly, the PELL grant, which is categorized under federal aid, is a subsidy provided by the federal government to students in need to pay for college. This aid is given mostly to undergraduate students but also some graduate students in certain post-baccalaureate programs. Students receive this aid by applying the Free Application for Federal Student Aid (FAFSA) and demonstrating need. Unlike loans, students who receive PELL grants do not have to repay. According to Federal Students Aid, the maximum PELL grant award for the $2020 / 2021$ academic year is $\$ 6,345$. In order for students to be eligible for this kind of aid, they need to be enrolled in a degree or certificate program at an accredited higher education institution to receive the aid. In addition to the aforementioned eligibility requirement, the students have to demonstrate financial need, maintain satisfactory academic progress (mostly a GPA of 3.0 or higher), and be registered with the selective service (Federal Students Aid, n.d.).

Secondly, the Stafford loans are low-interest rate loans that are awarded to undergraduate or graduate students. Stafford Loans can be subsidized or unsubsidized. Subsidized Stafford loans are awarded to students with financial needs with an interest rate of $4.53 \%$ that is usually paid by the federal government as they accrue. On the other hand, the unsubsidized Stafford loans are available to both undergraduate and graduate students and professional students (financial need is not required) with an interest rate of $6.08 \%$, with the exception of undergraduates who pay $4.53 \%$. Unlike the subsidized Stafford loan, borrowers of the unsubsidized Stafford loan are responsible for paying the accrued 
interest. Stafford loan borrowers are required to repay with a grace period of six months after school. However, there are extended repayment plans (Library of Congress, 2005; Federal Students Aid, n.d.). Also, there is the Parent Loan for Undergraduate Students (PLUS), which is available to parents in order to pay for their ward's college expenses with an interest rate of $7.08 \%$. The federal loans are awarded through the U.S. Department of Education (Federal Students Aid, n.d.).

Aside from the federal aid discussed above, the United States also has State Aid awarded to students. The State Aid is in the form of grants or scholarships awarded to students as merit-based or need-based. Merit-based state aid is awarded based on academic performance, and receivers are not required to repay. On the other hand, need-based state aid is awarded to students who demonstrate financial need through the application (College Planning Center of Rhode Island, 2020; Federal Students Aid, n.d.). Lastly, there is also institutional aid in the form of grants to help recruit students into various programs in institutions of higher education.

According to the NCES (2019), 85\% of first-time students in a four-year institution of higher education received financial aid in the form of Pell grants and loans in the 2016/2017 academic year. However, the percentage was 75 in the 2000/2001 academic year. These include all aids that went directly to the students but excluded loans paid directly to parents. These percentages include students in both public and private schools. This shows about a $10 \%$ increase in the number of students who depend on some form of financial aid to enroll in higher education.

\section{Findings}

This section of the paper outlines and discusses the findings from the analysis of the goals, enrollment, expenditure, and sources of funding in Ghana and the U.S. The first part analyzes the similarities between the two countries' higher education relating to the limited access to education and the goals established for their higher education institutions. The second part analyzes the difference between the two countries.

According to Ghana's 1992 constitution, access to education at all levels in Ghana is supposed to be free to all irrespective of financial background, but this is not the case due to inadequate government funds to support higher education. Given that there is limited financial aid, especially for students from low socioeconomic backgrounds who may not have a personal guarantor to secure a loan from the SLTF, they would have to pay from pocket or forget about enrolling in higher education. The limited access to higher education and the complications of securing a student loan gives students with high socioeconomic background more access to higher education than those with low socioeconomic background (Okrah \& Adabor, 2010). Also, the government is more committed to ensuring free secondary education for all and, as a result, allocates more funds to the secondary education sector. Similarly, education in the U.S. is intended to be accessible to all. However, not all students can enroll or graduate due to increased tuition, a decrease in government funding for schools, and the continuing financial barriers that limit the low-income family's access to higher education compared to their high-income 
family counterparts (Tulip, 2007). This idea suggests that higher education is still not accessible to all citizens, whether in a super-power nation-state or a developing country.

The goals for higher education emphasize accountability and competition in both countries. A careful analysis of the established goals of higher education in Ghana and the U.S. seem to be geared towards competing in the global education sphere. It also reveals the demand for standardization and accountability across all higher education institutions. As a developing country, Ghana's goal relative to education is focused on establishing a solid foundation for improving the quality of education, which seems like an indisputable vision for every developing country. However, there seem to be evidence of using neoliberal practices such as standardizing disciplines and creating competition among schools. Also, the goal of achieving a demand-driven form of higher education reveals the influence of knowledge-based economy (Sum \& Bob, 2013). As a developed country and a super-power, the U.S. obviously has achieved a greater foundation and now seeks excellence in higher education through accountability. That is, the higher education goals in both countries seem to be influenced by neoliberalism, which prioritizes competition and commodifies higher education institutions (Harvey, 2010). Performance-based funding, a product of neoliberalism, has been enacted to enforce standardization, accountability, and competition among schools in the U.S. and lately in Ghana (Dougherty \& Natow, 2019; Hagood, 2019; Zumeta \& Li (2016).

The U.S. has more sources of funding than Ghana. In the U.S., there are more sources of financial aid available to students to pay tuition. These aids, such as the Pell grants and the Stafford loans, go directly to individual student accounts to pay their fees. In Ghana, there are limited financial aids to support students, especially those from underprivileged families. The government's subsidy distributed to the various universities helps subsidize the fees for all regular students. This suggests that all regular students pay the same fee, which is subsidized by the government (Dadzie, 2009). This, however, does not apply to the fee-paying students who pay full fees without any subsidy from the government. Also, international institutions like the World Bank and the IMF contributed to cutting down funding for higher education in Ghana (Britwum \& Martins, 2008; Dadzie, 2009). Ghana's partnership with the World Bank and the IMF in the 1980s resulted in the Structural Adjustment Program (SAP) managed by these organizations. The World Bank and the IMF directed the government to reduce funding for higher education and rather increase expenditure for basic education (Britwum \& Martins, 2008; Dadzie, 2009). The adaptation of the SAP ensured that demands of higher education did not divert the demands of the World Bank and the IMF (Britwum \& Martins, 2008).

Female enrollment is less in Ghanaian higher education. In terms of gender, there are more males who enroll in higher education in Ghana than females. For example, Ghana had a $13.6 \%$ gross enrollment ratio for females enrolled in 2018, against a $17.7 \%$ gross enrollment ratio for males in the same year (UNESCO Institute of Statistics, 2021). On the contrary, the U.S. has more female enrollment than males in higher education. For instance, there was $102.4 \%$ gross enrollment for females in 2017, while males had a gross enrollment of 74.9\% (UNESCO Institute of Statistics, 2021). Also, in 2018, Ghana had a 
gross graduation ratio of $8.79 \%$ and $12.51 \%$ for females and males, respectively (UNESCO Institute of Statistics, 2021).

On the other hand, the OECD (2021) reports that females' 2017 graduation rate in the U.S. was $66.9 \%$, while males had $46.0 \%$. This data shows the disparities in enrollment and graduation between genders in the two countries. It shows that the United States has more females enrolling in higher/tertiary education than males. However, this is not the case for Ghana, where more males enroll and graduate from higher education institutions than their female counterparts. This suggests that women in Ghana may not have attained equal access to higher education as men. Studies have found that access to higher education in Ghana favors males and those from high socioeconomic backgrounds than females and students from low-income families (Atuahene \& Owusu-Ansah, 2013). In a doctoral dissertation written by Dadzie (2009), he commented on how families would rather send their boys to school other than girls due to the patriarchal nature of most Ghanaian societies where men are seen as the dominant or heads of families. The author also indicated how the colonizers sent boys to Europe to further their education, leaving behind girls (Dadzie, 2009).

The U.S. has a higher enrollment and graduation rate than Ghana. From the data, there seems to be a low enrollment and graduation rate in general in the case of Ghana compared to the U.S. This could be a result of the inability of the various institutions to increase their intake due to lack of infrastructural development and expansion of facilities. The limited facilities such as lecture halls, limited space libraries, and resources prevent institutions from admitting more students (Asamoah, 2017). Also, Acheampong (2010) found that the loans available to the students in Ghana are insufficient and that support from relatives was more reliable to the students who participated in the study. The available public funding for students is not enough to pay the high cost of higher education, especially the private sector, making enrollment and graduation favorable to students from high socioeconomic backgrounds (Asamoah, 2017; Atuahene \& OwusuAnsah, 2013; Yusif, Ishak, \& Zulkifly, 2013). This shows a major characteristic of neoliberalism: favoring the elite over those from low-income families regarding higher education access (Gyamera \& Burke, 2018).

\section{Conclusion}

This paper explored the higher education finance between Ghana and the U.S. as countries with a historical connection in education which continues to some extent in today's higher education. The goals of both countries were outlined and discussed. The paper also explored the enrollment trend in each country and the extent to which each of the countries invests in their institutions of higher education. As a world "super-power," the U.S. invests much more in education than Ghana, a developing country. This is manifested through the number of higher institutions established in the various countries and the sources of financial aid available to university students in both countries. Also, the gross enrollment rate in higher education, especially for females in the U.S., is much higher than that of Ghana. This could mean how well the United States is established in terms of gender policies to ensure equitable access to higher education by all genders. 
Nonetheless, in all these disparities in Higher education between the two countries, there is a common ground for them all, and that is the diminishing government support in terms of funding to the schools and the students as well as the limited access to students from low socioeconomic backgrounds. This is seen as an adverse effect of neoliberalism, which considers privatization as the basis for every nation-state's development. As a global rule, neoliberalism is enforced by superstructures such as the World Bank and the IMF, who see to it that countries make adjustments to their structures and policies, giving more power to free-market, private property rights, and capitalism. The pressure from these international organizations is usually felt by the developing countries more than the developed countries.

To understand the impact of the sources of funding in both countries, there should be more future research on the percentage of cost covered by these aids. Also, there should be future research on the awareness of these sources of financing available to students in both countries.

Alfred Acquah is a doctoral student in Curriculum and Instruction with emphasis on Cultural Studies, International Education, and Multicultural Education at the University of Nevada, Las Vegas.

\section{References}

Acheampong, A. B. (2010). Meeting the financial needs of tertiary students: the role of students loan trust fund (SLTF): The case study of New Juaben municipality [Unpublished master's thesis]. KNUST.

Altbach, P. (2015). Higher education and the WTO: Globalization run amok. International Higher Education, 23. https: / / doi.org/10.6017/ ihe.2001.23.6593

Asamoah, M. K. (2017). Access to undergraduate education is an unresolved burden in Ghana. International Journal of Lifelong Education, 36(5), 595-612. https: / / doi.org/10.1080/02601370.2017.1356880

Atuahene, F. (2008). The challenge of financing higher education and the role of student loans scheme: An analysis of the Student Loan Trust Fund (SLTF) in Ghana. Higher Education, 56(4), 407-421. https: / / doi.org/10.1007/ s10734-007-9101-5

Atuahene, F. (2006). A policy analysis of the financing of tertiary education institutions in Ghana: An assessment of the objectives and the impact of the Ghana Education Trust Fund [Unpublished doctoral dissertation]. Ohio University

Atuahene, F. (2015). Higher education finance in Ghana. International Higher Education, 50. https: / / doi.org/10.6017/ihe.2008.50.7996 
Atuahene, F., \& Owusu-Ansah, A. (2013). A descriptive assessment of higher education access, participation, equity, and disparity in Ghana. SAGE Open, 3(3), https: / / doi.org/10.1177/2158244013497725

Badoo, C. (2013). Internationalization and the challenges of gender equality in higher education: The case of Ghana. In C. Sehoole \& J. Knight (Eds.), Internationalization of African higher education: Towards achieving the MDGs (pp. 33-52). Sense Publishers.

Becker, R., \& Kolster, R. (2012). International student recruitment: policies and developments in selected countries. NUFFIC.

Britwum, A. O., \& Martins, P. (2008). The challenges of globalization, labor market restructuring, and union democracy in Ghana. African Studies Quarterly, 10(2), 125.

College Planning Center of Rhode Island. (2020). Need-based financial aid vs merit-based aid. Rhode Island Student Loan Authority. https://blog.risla.com/need-basedfinancial-aid-vs-merit-based-aid

Dadzie, D. S. (2009). Cost sharing and equity in higher education: Experiences of selected Ghanaian students. (Publication No. 304963764) [Doctoral dissertation, Ohio University]. ProQuest Dissertation Publishing.

Darves, P., Gao, S., Shen, Y., \& Bawany, B. (2017). Sharing higher education's promise beyond the few in Sub-Saharan Africa. World bank Group. https: / / openknowledge.worldbank.org/bitstream/handle/10986/27617/978146 4810503.pdf? sequence $=2 \&$ isAllowed $=\mathrm{y}$

Data Lab (n.d.). How much was invested in colleges and universities? https: / / datalab.usaspending.gov / colleges-and-universities /

Doh, B. T. S., \& Doh, P. S. (2013). Performance-based funding dynamics for the enhancement of strategic objectives in higher education in Sub-Saharan Africa: An institutional case in Cameroon. Open Journal of Education, 1(4), 122-129.

Duffin, E. (2020, November 5). College enrollment in public and private institutions in the U.S. 1965-2029. Statista. https://www.statista.com/statistics/183995/us-collegeenrollment-and-projections-in-public-and-private-institutions /

Dougherty, K. J., Jones, S. M., Lahr, H., Natow, R. S., Pheatt, L., \& Reddy, V. (2014).

Performance funding for higher education: Forms, origins, impacts, and futures. The Annals of the American Academy of Political and Social Science, 655(1), 163-184. https: / / doi.org/10.1177/0002716214541042 
Dougherty, K. J., \& Natow, R. S. (2019). Analyzing neoliberalism in theory and practice: The case of performance-based funding for higher education. Centre for Global Higher Education. https:/ / www.researchcghe.org/perch/resources/publications/cgheworking-paper-44.pdf

Dougherty, K. J., \& Natow, R. (2015). The politics of performance funding. Johns Hopkins University Press.

Emeka, B. (2020, March 23). GETFund scholarships for Ghanaian students 2020-2021 Global Scholarship Forum. https://worldscholarshipforum.com/getfundscholarship/

Enterversity (2021). Cost of university education in Ghana. Entervasity. https: / / www.entervarsity.com/noticeboard/ cost-of-university-education-in ghana-2

Federal Students Aid (n.d.). You must meet certain requirements to qualify for federal student aid (grants, work-study, and loans). https://studentaid.gov/understandaid/eligibility/requirements.

Ghana Education Service [GES] (n.d.). Technical and vocational education division. https: / /ges.gov.gh/2019/07/15/technical-and-vocational-education-division /

Ghana Education Trust Fund [GETFund] (2021). Welcome message from administrator. http: / / www.getfund.gov.gh/

Ghana Tertiary Education Commission [GTEC] (2021). Strategic plan. https: / / gtec.edu.gh/strategic-plan

Goode, F. (2017). Approaches to Ghana's higher education challenges drawn from the U.S. community college model (Publication No.10687133) [Dissertation, Walden University]. ProQuest Dissertations \& Theses Global.

Gyamera, G. O., \& Burke, P. J. (2018). Neoliberalism and curriculum in higher education: A post-colonial analyses. Teaching in Higher Education, 23(4), 450-467. https: / / doi.org/10.1080/13562517.2017.1414782

Hagood, L. P. (2019). The financial benefits and burdens of performance funding in higher education. Educational Evaluation and Policy Analysis, 41(2), 189-213. https: / / doi.org/10.3102/0162373719837318

Harvey, D. (2007). Neoliberalism as creative destruction. The Annals of the American Academy of Political and Social Science, 610(1), 22-44. https: / / doi.org/10.1177/0002716206296780 
Klein, M. W. (2015). Settling a U.S. senatorial debate: Understanding declines in state higher education funding. Journal of Education Finance, 41(1), 1-29. https: / / www.jstor.org/ stable/24459298

Lee, J. J. (2010). International students' experiences and attitudes at a US host institution: Self-reports and future recommendations. Journal of Research in International Education, 9(10), 66-84. https: / / doi.org/10.1177 / 1475240909356382

Library of Congress. Congressional Research Service. (2005). Federal Perkins loans and FFEL/DL Stafford loans: A brief comparison. https: / / www.everycrsreport.com/reports/RL32854.html

Liu, J. (2018). Economic recession and school finance: A cross-national study. In I. BeDavid-Hedar (Ed.). Education finance, equality, and equity (pp. 93-111). Springer International Publishing Ag.

Marginson, S. (2016). High participation systems of higher education, The Journal of Higher Education, 87(2), 243-271. https: / / doi.org/10.1080/00221546.2016.11777401

Ministry of Education, Ghana, (n.d.). About us: The ministry of education. http: / / moe.gov.gh/index.php/about-us/

Morton, P. G. (2018). Higher education - Is the value worth the cost? Journal of Professional Nursing, 34(5), 327-328. https: / / doi.org/10.1016/j.profnurs.2018.08.001

National Association for Foreign Student Affairs [NAFSA]. (2020). Losing talent 2020: An economic and foreign policy risk America can't ignore. Retrieved August 10, 2020, from https: / / www.nafsa.org/policy-and-advocacy/ policy-resources / losing-talenteconomic-and-foreign-policy-risk-america-cant-ignore

National Center for Education Statistics [NCES] (2017). Degree-granting postsecondary institutions, by control and classification of institution and state or jurisdiction: 20162017. https: / / nces.ed.gov/programs / digest/d17/tables/dt17_317.20.asp

National Center for Education Statistics [NCES] (2020). College enrollment rates. https: / / nces.ed.gov/programs/coe/indicator_cpb.asp

National Center for Education Statistics [NCES] (2019). Table 605.20. Government and private expenditures on education institutions as a percentage of gross domestic product, by level of education and country: Selected years, 2005 through 2016. https: / / nces.ed.gov/programs / digest/d19/tables/dt19_605.20.asp

National Center for Education Statistics [NCES] (2019), Price of attending an Undergraduate institution.https: / / nces.ed.gov/programs / coe/pdf/Indicator_CUA/coe_cua_20 19_05.pdf 
Newkirk P. (2012). Tuskegee, Achimota and the construction of black transcultural identity. (Publication No. 1015660922) [Doctoral dissertation, Columbia University]. ProQuest Dissertations Publishing.

Newman, E., \& Duwiejua, M. (2015). Models for innovative funding of higher education in Africa-The case in Ghana. In P. Okebukola (Ed.), Towards Innovative models for funding higher education in Africa (pp. 1-23). Association of African Universities.

Organization for Economic Co-operation and Development [OECD]. (2021). Tertiary graduation rate (indicator). OECD iLibrary. http: / / doi.org/10.1787 / 15c523d3-en

Okrah, K., A., \& Adabor, J. (2010). Rethinking free education: How higher education shortchanges and denies access to the less privileged in Africa--the case of Ghana. Michigan Academician, 40(1), 1-11.

Oseni, G., Huebler, F., McGee, K., Amankwah, A., Legault, E., \& Rakotonarivo, A. (2018). Measuring household expenditure on education: A guidebook for designing household survey questionnaires. The World Bank. http: / / documents1.worldbank.org/curated/en/494931587033216249/pdf/Meas uring-Household-Expenditure-on-Education-A-Guidebook-for-DesigningHousehold-Survey-Questionnaires.pdf

Pius, T. (2014). Sources of funding for higher education in Ghana. https: / / www.duo.uio.no/bitstream/handle/10852/41689/Twene-PiusThesis.pdf $\% 3$ Fsequence $\% 3 \mathrm{D} 1$

Ryan, C., L. \& Bauman, K. (2016). Educational attainment in the United States: 2015. https: / / www.census.gov/ content/dam/Census/library/publications / 2016/ de $\mathrm{mo} / \mathrm{p} 20-578 . \mathrm{pdf}$

Salmi, J. (2003). Student loans in an international perspective: The World Bank experience. The World Bank LCSHD paper series 44

Sasu, D. D. (2020, November 5). Number of tertiary students in Ghana 2019, by type of education. Statista. https://www.statista.com/statistics/1180524/ number-ofstudents-in-tertiary-education-in-ghana /

Schugurensky, D. (2013). Higher education in the era of globalization: Toward a heteronomous model? In R. Arnove, C. Torres, \& S. Franz (Eds.), Comparative education: The dialectic of the global and the local (4th ed., pp. 293-314). Rowman \& Littlefield

St. George, E. (2006). Positioning higher education for the knowledge-based economy. Higher Education, 52(4), 589-610. https: / / doi.org/10.1007/ s10734-005-0955-0 
Steiner-Khamsi, G., \& Quist, H. O. (2000). The politics of educational borrowing. Comparative Education Review, 44(3), 272-299. https:/ / doi.org/10.1086/447615

Stromquist, N. P., \& Sanyal, A. (2013) Student resistance to neoliberalism in Chile. International Studies in Sociology of Education, 23(2), 152-178, https: / / doi.org/10.1080/09620214.2013.790662

Students Loan Trust Fund, (2020). Students Loan Trust Fund. https: / / www.sltf.gov.gh/about-us /

Sum, N. L., \& Bob, J. (2013). Competitiveness, the knowledge-based economy and higher education. Journal of the Knowledge Economy, 4(1), 24-44. https: / / doi.org/10.1007/ s13132-012-0121-8

The World Bank (2021). Government expenditure on education, total (\% of GDP) - Ghana. https: / / data.worldbank.org/indicator/SE.XPD.TOTL.GD.ZS?locations=GH

The World Bank, (2017). Higher Education.

https: / / www.worldbank.org/en/topic/tertiaryeducation

The World Bank. (1994). Higher education: Lessons of experience. International Journal of Educational Development, 15(2), 197-198. https://doi.org/10.1016/07380593(95)90057-8

Tulip, P. (2007, December 6). Financing higher education in the United States. OECD. https: / / dx.doi.org/10.1787/043760330834

U.S. Department of Education (n.d.). U.S. Department of Education. https: / www.ed.gov /

U.S. Department of Education (2019, March 21). Secretary DeVos issues statement on president Trump's higher education executive order. Retrieved from https: / / www.ed.gov/news / press-releases / secretary-devos-issues-statementpresident-trumps-higher-education-executive-order $\backslash$

U.S. Spending, (2020, February 10). U.S. total government spending breakdown in percent GDP. https: / / www.usgovernmentspending.com/percent_gdp

University of Ghana (2018). Welcome to the Students Financial Aid website. https: / / www.ug.edu.gh/aid/ welcome

United Nations Educational, Scientific and Cultural Organization (UNESCO) Institute of Statistics (2021). Ghana: Education and Literacy. http://uis.unesco.org/en/country/gh? theme=education-and-literacy.

United Nations Educational, Scientific and Cultural Organization (UNESCO) Institute of 
Statistics (2021). United States of America-Education and Literacy. http: / / uis.unesco.org/en / country / us?theme=education-and-literacy

Weis, L., Han, S. W., \& Jo, H. (2020). Social class and education. In J. A., Banks, \& C. A. M. Banks (Eds.), Multicultural education: Issues and perspectives (10 ${ }^{\text {th }}$ ed., pp. 43-59). John Wiley \& Sons, Inc.

Yusif, H., Ishak Y., \& Zulkifly O. (2013). Public university entry in Ghana: Is it equitable?" International Review of Education 59(1), 7-27. https: / / doi.org/10.1007/s11159-013-9331-y

Zumeta, W., \& Li, A. Y. (2016). Assessing the underpinnings of performance funding 2.0: Will this dog hunt? Trends and issues. TIAA Institute. https: / / www.tiaainstitute.org/ sites / default / files / presentations / 201702/ti_assessing_the_underpinnings_of_performance_funding_2.pdf 